\title{
Procedurele en distributieve rechtvaardigheid
}

\author{
Verslag van de voorjaarsvergadering 2014 van de Nederlandse Vereniging voor \\ Procesrecht
}

\author{
Mr.J.J. Dammingh en mr. P.E. Ernste*
}

Tijdens de voorjaarsvergadering van de Nederlandse Vereniging voor Procesrecht (hierna: NVvP) stond het onderwerp 'procedurele en distributieve rechtvaardigheid' centraal. Hierbij gaat het in essentie om de vraag aan welke eisen een procedure moet voldoen om de kans te maximaliseren dat een procespartij, ook als zij door de rechter in het ongelijk wordt gesteld, de procedure als 'rechtvaardig' ervaart en de uitkomst ervan kan accepteren. De vergadering, onder voorzitterschap van prof. mr. C.J.M. Klaassen, discussieerde over genoemd onderwerp naar aanleiding van inleidingen van prof. dr. K. van den Bos, mr. P.N. van Regteren Altena en mr. C.E. Drion.

De voorzitter licht het onderwerp toe. De laatste jaren is er veel aandacht besteed aan het verloop en de inrichting van de procedure. Daarbij hebben enerzijds diverse procesrechtelijke aspecten, zoals de substantiëringsplicht, de waarheidsplicht en de opstelling van de rechter in de procedure, in de belangstelling gestaan. Anderzijds is er ook aandacht geweest voor wat in de beleving van partijen een rechtvaardige procedure is, waarbij dan moet worden gedacht aan de bejegening van partijen door de rechter en het optreden van de rechter tijdens de zitting. Er zijn - op diverse niveaus - meerdere projecten geëntameerd gericht op hoe burgers een gerechtelijke procedure ervaren. De uiteenlopende opvattingen over wat justitiabelen als rechtvaardig ervaren, vormden voor het bestuur van de NVvP de directe aanleiding om tijdens deze vergadering te discussieren over de vraag wat er nodig is om een procedure in de beleving van procespartijen als rechtvaardig aan te merken, en in dit verband ook in te gaan op de vraag op welke wijze de rechter daaraan een bijdrage kan leveren, met name in het kader van de motivering van uitspraken.

Het onderwerp 'procedurele en distributieve rechtvaardigheid' werd vanuit het oogpunt van de advocatuur belicht door

Mr. J.J. Dammingh is universitair hoofddocent burgerlijk (proces)recht aan de Radboud Universiteit Nijmegen. Mr. P.E. Ernste is universitair docent burgerlijk (proces)recht aan de Radboud Universiteit Nijmegen. Dit is een bewerking van het verslag dat - samen met de tekst van de inleidingen - wordt opgenomen in een binnenkort te verschijnen uitgave van de Nederlandse Vereniging voor Procesrecht. mr. P.N. van Regteren Altena (advocaat te Amsterdam) en vanuit het oogpunt van de rechterlijke macht door mr. C.E. Drion (raadsheer bij de Hoge Raad). Daaraan voorafgaand liet prof. dr. K. van den Bos (hoogleraar sociale psychologie en hoogleraar empirische rechtswetenschap aan de Universiteit Utrecht) zich in zijn inleiding uit over de vraag welke oordelen en vooroordelen er bestaan over de procedurele en distributieve rechtvaardigheid.

\section{Inleiding prof. dr. K. van den Bos}

Stellingen:

1. Uiteindelijk gaat het mensen toch om materieel gewin.

2. Mensen zijn wantrouwender geworden.

3. Het ervaren van procedurele rechtvaardigheid is ondergeschikt aan het rechtssysteem.

\section{Inleiding}

Van den Bos richt zich in zijn inleiding op de vraag waarom procedurele rechtvaardigheid belangrijk is voor mensen en wat juristen naar zijn mening hieronder zouden moeten verstaan. Vaak is het zo dat directe informatie over het vertrouwen dat in maatschappelijke instituties - zoals de rechterlijke macht kan worden gesteld, onvoldoende aanwezig is of moeilijk te interpreteren. Juist in zo'n situatie van 'informatieonzekerheid' speelt 'ervaren procedurele rechtvaardigheid' (dat wil zeggen de mate waarin de rechtzoekenden zich eerlijk en rechtvaardig behandeld voelen door maatschappelijke instituties) een cruciale rol: mensen die gedurende hun interacties met (vertegenwoordigers van) maatschappelijke instituties op een eerlijke en rechtvaardige wijze worden behandeld, zullen eerder geneigd zijn deze maatschappelijke instituties en hun besluiten te aanvaarden (en ook meer vertrouwen hebben in deze instituties).

De 'ervaren procedurele rechtvaardigheid' wordt derhalve verondersteld een belangrijke rol te spelen bij de acceptatie van besluiten van (vertegenwoordigers van) maatschappelijke instituties en het vertrouwen in die instituties. Concreet gaat het om de rechtvaardigheid en eerlijkheid van de bejegening en behandeling van rechtzoekenden door rechters, advocaten en anderen van het justitiële systeem. Van den Bos onder- 
scheidt vier componenten die (samen) 'ervaren procedurele rechtvaardigheid' bewerkstelligen: (1) de vraag of mensen op een beleefde manier en met respect zijn behandeld, (2) de vraag of mensen hun mening konden geven en het idee hebben dat naar hun mening werd geluisterd, (3) de kwestie of mensen zich eerlijk behandeld en rechtvaardig bejegend voelen, en (4) de vraag of mensen het idee hebben dat ze met competente en professionele personen van doen hebben. Van den Bos benadrukt dat de wijze waarop procedurele rechtvaardigheid precies moet worden gemeten, nog onderwerp van debat is. Er is al het nodige onderzoek verricht naar de effecten van procedurele rechtvaardigheid in juridische context en de resultaten daarvan zijn bemoedigend (in die zin dat een hoge mate van 'ervaren procedurele rechtvaardigheid' tot meer tevredenheid over de uitkomst van de procedure lijkt te leiden), maar volgens Van den Bos dient er nog meer onderzoek te worden gedaan op juridisch gebied om 'harde' conclusies te kunnen trekken.

\section{Discussie}

Ahsmann (rechter bij de Rechtbank Den Haag, tevens bijzonder hoogleraar rechtspleging aan de Universiteit Leiden) stelt Van den Bos de vraag in hoeverre zijn inleiding ook van toepassing is op de rechtspraak, omdat daar het contradictoire element speelt. Daarnaast vraagt zij zich af wat de invloed is van het winnen of het verliezen van een zaak op de beleving van partijen, voor zover het 'procedurele rechtvaardigheid' betreft.

Van den Bos geeft aan dat hij nog onvoldoende weet van de rechtspraak om daar iets over te kunnen zeggen. Volgens hem wordt de ervaring van procedurele rechtvaardigheid vaak al gevormd vóórdat de informatie over de uitkomst (van de procedure) wordt verkregen. Van den Bos geeft als voorbeeld dat de procedurele rechtvaardigheid veelal zal worden gekleurd door de interactie met de rechter, waarbij dan een rol speelt of de partij gedurende de procedure eerlijk is bejegend en serieus is gehoord. Dit kan dan vervolgens de reactie van een partij op de uitkomst van de procedure beïnvloeden. Dat een partij achteraf door de uitkomst negatiever tegen de zaak aan kijkt, komt volgens Van den Bos wel voor, maar minder vaak. Dat heeft volgens hem te maken met de volgorde waarin een partij de informatie verwerkt: eerst de procedure en pas daarna de uitkomst.

Meijer (raadsheer bij het Hof Amsterdam) stelt naar aanleiding van de opmerking van Van den Bos dat mensen vaak wat tijd nodig hebben om van de 'eigen-belangmodus' naar de 'groter-belangmodus' te komen, de vraag hoeveel tijd mensen hiervoor doorgaans nodig zullen hebben. Meijer is rechter en is hierin geïnteresseerd in de context van zittingen waar een rechter met partijen in gesprek wil gaan en mogelijk tot een schikking wil komen. Meijer vraagt zich daarom af of Van den Bos iets kan zeggen in termen van minimale zittingsduur.

Van den Bos antwoordt dat hoe mensen zullen reageren afhankelijk is van de informatie die zij ontvangen. Wanneer de informatie niet eenvoudig te interpreteren is, zal dit langer duren. Dit geldt volgens hem voor partijen die in de rechtszaal komen. De rechter dient er volgens Van den Bos voor te zorgen dat hetgeen hij zegt voor partijen goed te interpreteren is. Een advocaat kan ook behulpzaam zijn door een beschikking of een vonnis aan partijen uit te leggen. Wanneer dit gebeurt, zal een partij weinig tijd nodig hebben en kan het snel gaan. Wanneer de informatie voor partijen niet goed is te interpreteren, kan dat tot gevolg hebben dat partijen er allerlei 'perifere zaken' bij halen.

Wiersma (gastdocent aan de Universiteit van Amsterdam) merkt op dat hij in het verhaal van Van den Bos gelukkig niet proefde dat mensen wantrouwend zijn, en hij stelt daarom de vraag of diens tweede stelling wel juist is.

Van den Bos antwoordt dat hem is gevraagd prikkelende stellingen naar voren te brengen. Dat heeft hij gedaan met zijn stelling dat 'mensen wantrouwender zijn geworden'. Het staat wat hem betreft echter niet vast dat dit werkelijk zo is. Uit onderzoeken naar 'vertrouwen' die in de krant zijn terug te vinden, zou dit wel af te leiden zijn, maar Van den Bos mist hierin (de verwerking van) het feit dat mensen vaak licht sceptisch zijn doordat zij over onvoldoende informatie beschikken. Dit betekent volgens hem niet dat ze wantrouwender zijn geworden. De niet-wetende mens gaat volgens Van den Bos op zoek naar vervolginformatie.

\section{Inleiding mr. P.N. van Regteren Altena}

Stelling: Noblesse oblige. Ook advocaten hebben een zekere verantwoordelijkheid voor een rechtvaardige uitkomst van het proces. Dit kan betekenen dat de advocaat ook rekening houdt met de gerechtvaardigde belangen van de wederpartij. Procesverstorend gedrag ${ }^{1}$ is hoe dan ook uit den boze.

\section{Inleiding}

Van Regteren Altena behandelt het onderwerp 'procedurele en distributieve rechtvaardigheid' vanuit het perspectief van de advocaat. Uit bovenstaande stelling leidt hij een drietal onderwerpen af. Allereerst het onderwerp dat advocaten een zekere verantwoordelijkheid hebben voor een rechtvaardige uitkomst van het proces. In dit kader bespreekt Van Regteren Altena de vijf kernwaarden van de advocatuur (onafhankelijkheid, onpartijdigheid, deskundigheid, integriteit en vertrouwelijkheid), alsmede de preambule 'algemeen belang van een goede rechtsbedeling, waarmee de advocaat rekening dient te houden. Het tweede onderwerp dat Van Regteren Altena naar aanleiding van de stelling bespreekt, is de grens tussen enerzijds het belang van de cliënt en anderzijds nodeloos procesverstorend gedrag. Hij maakt een onderscheid tussen procesverstorend gedrag en professionele onzorgvuldigheid, en geeft in dit verband een lijst van voorbeelden die zien op procesverstorend gedrag in schriftelijke stukken en procesverstorend gedrag ter zitting, ontleend aan het onderzoek $D e$ goede proces-

1. Deze term is ontleend aan het - in opdracht van de Raad voor de rechtspraak in 2011 tot stand gekomen - rapport De goede procesorde in beeld. Procesverstorend gedrag werd bij meer dan de helft van het aantal geobserveerde zittingen waargenomen. 
orde in beeld. ${ }^{2}$ Volgens Van Regteren Altena speelt bij de vraag of gebruik moet worden gemaakt van procesverstorend gedrag, een rol of de cliënt een sterke dan wel een zwakke zaak heeft. Voor het gebruik maken van procesverstorende gedragingen is volgens hem in ieder geval nodig dat dit in overleg met de client gebeurt (en schriftelijk wordt vastgelegd). Het derde aspect dat Van Regteren Altena naar aanleiding van de stelling bespreekt, is dat de advocaat ervoor dient te zorgen dat zijn client met de beslissing kan leven. Hiervan geeft hij een aantal voorbeelden, zoals voorlichting van de cliënt, het waarschuwen voor de risico's, de cliënt voorbereiden op de zitting, waarbij ook de mogelijkheid van een schikking aan de orde komt, het veiligstellen van de spreektijd, (zo mogelijk) bewerkstelligen dat de rechter die de comparitie of het pleidooi heeft voorgezeten ook het vonnis wijst, en zo nodig kritische advisering over het instellen van hoger beroep.

\section{Discussie}

De voorzitter dankt Van Regteren Altena voor zijn betoog en is benieuwd hoe men in de zaal aan kijkt tegen het door hem gemaakte onderscheid tussen professionele zorgvuldigheid en procesverstorend gedrag. De voorzitter brengt in het bijzonder onder de aandacht de opmerking van Van Regteren Altena dat - kort samengevat - bij een 'zwakke' zaak procesverstorend gedrag zinvol kan zijn, maar dat hiervoor wel de instemming van de cliënt nodig is. De voorzitter refereert aan deze opmerking omdat haar gedachte zou zijn dat de advocaat de cliënt moet beteugelen en corrigeren, en de opmerking van Van Regteren Altena zou meebrengen dat de cliënt de advocaat zou moeten beteugelen en corrigeren.

Röell (rechter bij de Rechtbank Noord-Nederland) vraagt zich af hoe de - niet door Van Regteren Altena besproken gedragsregel van welwillendheid die advocaten tegenover elkaar moeten betrachten, zich verhoudt tot procesverstorend gedrag. Röell verwijst daarbij naar het boek Geachte confrère, waarin schrijver en advocaat F. Bordewijk beschrijft hoe hij een dagvaarding in concept naar de advocaat van de wederpartij stuurt en per post een pikerende brief terugkrijgt waarin

2. M. Barendrecht, S. Gulijk, M. Gramatikov \& P. Sluijter, De goede procesorde in beeld, Den Haag: Sdu Uitgevers 2011. Te raadplegen via <www. rechtspraak.nl>. Op basis van dit onderzoek heeft Van Regteren Altena de volgende voorbeelden van procesverstorend gedrag in schriftelijke stukken gegeven: (1) zaken van onvoldoende gewicht, (2) formele fouten in processtukken, (3) stukken niet overleggen, (4) stellingen niet onderbouwen, (5) vordering/verweer niet juridisch onderbouwen, (6) vordering te ruim geformuleerd, (7) nieuwe verweren, (8) late vermeerdering van eis, (9) warrig procederen, (10) structuur stukken, (11) toon stukken, (12) te veel producties, (13) bedoeling producties onduidelijk, (14) stellen/ontkennen tegen beter weten in, (15) insinueren, (16) uitstel forceren, (17) verkeerd citeren, (18) vindplaatsen niet vermelden, (19) vindplaatsen verkeerd vermelden en (20) kansloze tegenvorderingen. Voorbeelden van procesverstorend gedrag ter zitting: (1) onnodig pleidooi vragen, (2) veel verhinderdata, (3) uitstel vragen, (4) inhoudelijke voorbereiding onvoldoende, (5) voorbereiding van cliënt onvoldoende, (6) langs essentie pleiten, (7) uitsluitend/te veel herhaling schriftelijke standpunten, (8) herhaling mondelinge standpunten, (9) niet reageren op signalen van de rechter, (10) schikking frustreren, (11) bejegening rechter en (12) bejegening advocaat wederpartij. deze advocaat hem wijst op drie nietigheden omdat hij van hem wil en zal winnen, maar niet op deze wijze (dat wil zeggen via de nietigheden). Röell stelt de vraag of de (confraternele) welwillendheid zo ver mag gaan, of dat een advocaat gerechtigd is procesverstorend gedrag te vertonen.

Volgens Van Regteren Altena geldt als kernwaarde dat een advocaat dient te staan voor zijn cliënt. Deze kernwaarde dient volgens hem wel te worden afgewogen tegen de welwillendheid tussen advocaten onderling, maar het belang van de cliënt prevaleert. Dit betekent volgens Van Regteren Altena echter niet dat de advocaat alles moet doen wat de cliënt hem opdraagt; hij dient zich af te vragen of het zinvol is in het licht van wat hij wil bereiken. De welwillendheid zit naar het idee van Van Regteren Altena niet zozeer in de inhoudelijke kant van de zaak, maar wel bijvoorbeeld bij uitstel in een procedure of bij het meewerken aan het herstel van de fout dat iemand per ongeluk een akte niet-dienen heeft gekregen. Van Regteren Altena spreekt dan van professionele welwillendheid. Wanneer hier geen medewerking aan wordt verleend, schiet men daar volgens hem ook niet veel mee op, omdat de uitspraak in de regel aan hoger beroep is onderworpen. Professionele welwillendheid speelt volgens Van Regteren Altena ook een rol bij de toon die advocaten tegenover elkaar aanslaan. Deze dient volgens hem zakelijk en professioneel te zijn. Hij is van mening dat procesverstorend gedrag is toegestaan ten aanzien van de aanpak van de zaak, maar dat de advocaat zich steeds dient af te vragen wat uiteindelijk het werkelijke belang is dat ermee is gemoeid.

Tonkens (oud-rechter, arbiter en bindend adviseur te Amsterdam) vraagt zich af of zij Van Regteren Altena goed heeft begrepen in de zin dat procesverstorend gedrag een bewuste keuze is van de advocaat, waarmee ook nog de cliënt instemt. Volgens haar denken veel rechters dat het geen bewuste keuze is, maar een slechte wijze van procederen.

Van Regteren Altena antwoordt dat hij een onderscheid heeft willen maken tussen procesverstorend gedrag in het belang van de cliënt en procesverstorend gedrag dat niet in het belang is van de cliënt. In het geval dat de cliënt van het procesverstorend gedrag nadeel ondervindt, heeft hij het onprofessioneel gedrag genoemd. Onprofessioneel gedrag vindt volgens hem plaats zonder dat men daarvoor heeft gekozen of men zich er bewust van is.

Gerretsen (advocaat te Rotterdam) wijst erop dat de lijst van procesverstorende gedragingen die Van Regteren Altena ontleent aan het onderzoek De goede procesorde in beeld wel erg breed is. Een deel van de procesverstorende gedragingen op deze lijst wordt volgens Gerretsen gevormd door een gebrek aan professionele deskundigheid. Dit is volgens hem wel procesverstorend, maar een gebrek aan professionaliteit en daardoor geen bewuste keuze. Daarnaast zijn er volgens Gerretsen gedragingen die wel procesverstorend zijn, maar op goede gronden zijn gedaan. Hij denkt aan het vragen van uitstel. Deze gedragingen moeten volgens hem dan ook niet worden gesanctioneerd. Er staat volgens Gerretsen een groot aantal 
gedragingen op de lijst die niet zouden moeten worden getolereerd, en het gaat hem te ver dat hierover een afstemming tussen advocaat en cliënt plaatsvindt. Dit raakt immers de basisvoorwaarden van de advocatuur, in die zin dat een advocaat zijn beroep op een betamelijke wijze behoort uit te voeren. Het belang van de cliënt moet volgens hem wel vooropstaan, maar dit wordt beperkt door andere belangen, en de betamelijkheid van de beroepsuitoefening brengt mee dat die andere belangen moeten worden meegewogen.

Van Regteren Altena geeft aan dat hij het eens is met Gerretsen en dat hij de lijst met procesverstorende gedragingen in de stukken en ter zitting heeft overgenomen uit het onderzoek. Een goede procesorde in beeld. Van Regteren Altena heeft bedoeld dat procesverstorend gedrag als tactiek zorgvuldig met de cliënt moet worden besproken. Hij geeft dan voorbeelden als het aanvragen van een faillissement om druk uit te oefenen, het risicoloos procederen in de vorm van een voorlopig getuigenverhoor of voorlopig deskundigenbericht, of het op een procedure laten aankomen in de hoop dat daarmee een soort financiële druk wordt gecreëerd, om zo een schikking te bereiken. Van Regteren Altena is zich ervan bewust dat rechters procesverstorend gedrag in stukken of ter zitting voor een groot deel kwalificeren als onvoldoende professionaliteit (en onvoldoende welwillendheid) van advocaten.

\section{Inleiding mr. C.E. Drion}

Stellingen:

1. Een rechterlijke uitspraak schrijf je voor de verliezer.

2. De standaardmotiveringen, zoals 'Daaraan doet niet (in voldoende mate) af hetgeen door partij $\mathrm{X}$ naar voren is gebracht', moeten in de ban gedaan worden, tenzij in standaardsituaties.

3. De aandacht voor bewijslevering is in Nederlandse procedures onder de maat.

\section{Inleiding}

Drion opent zijn inleiding met de uitspraak 'Recht is iets kroms dat verbogen is.' Deze uitspraak raakt volgens hem de procedurele rechtvaardigheid, omdat zij wordt gebruikt door rechtzoekenden die van oordeel zijn dat in hun zaak procedurele rechtvaardigheid heeft ontbroken. De uitspraak zegt volgens Drion ook iets over het proces van rechtsvinding.

Drion geeft aan het begin van zijn inleiding aan dat hij de volgende onderwerpen zal bespreken: (1) de veranderende rol van de rechter: van lijdelijk naar (meer) leidend, (2) de motiveerstijlen en tradities, om uit te komen bij de moderne stijl en het adagium 'Een uitspraak schrijf je voor de verliezer', en (3) de procedurele rechtvaardigheid in het proces ('the day in court' en de vraag welke rol de rechter zou moeten vervullen om bij te dragen aan procedurele rechtvaardigheid in alle onderdelen van het proces). Drion wil zijn inleiding afsluiten met de synthese: welke nieuwe rol zou procedurele rechtvaardigheid kunnen spelen?

Drion stelt voorop dat de rol van de rechter als gevolg van het geldende beginsel van partijautonomie beperkt is, waardoor zijn rol om bij te dragen aan de procedurele rechtvaardig- heid ook een beperkte is. Hij werpt de vraag op aan welke eisen het vonnis moet voldoen om (meer) bij te dragen aan de procedurele rechtvaardigheid. In art. 230 van het Wetboek van Burgerlijke Rechtsvordering (Rv), dat aanwijzingen voor het vonnis bevat, staat weinig tot niets over de motivering van de uitspraak. Volgens de Franse traditie heeft het vonnis een teleologische opbouw: uitsluitend de argumenten vóór de beslissing worden (uitgebreider) vermeld. Andere tradities, zoals de Duitse en de Anglo-Amerikaanse, stellen meer eisen aan de motivering van de uitspraak. De Nederlandse rechter schuift volgens Drion langzaam op naar een 'middenpositie'. Hij poneert als centrale stelling dat het zo goed mogelijk motiveren van het rechterlijk oordeel belangrijk is voor de procedurele rechtvaardigheid. Rechters moeten volgens hem geen - althans zo min mogelijk - gebruik maken van doelredeneringen en standaardafdoeningen (zoals: 'Daaraan doet niet (in voldoende mate) af hetgeen door partij $\mathrm{X}$ naar voren is gebracht'), omdat een uitspraak dan niet wordt geschreven voor de verliezer. Dit geldt overigens zowel voor de Hoge Raad als voor iedere feitenrechter. De rechter dient ook terughoudend om te gaan met 'trucs' als de stelplicht, vermoedens en tegenbewijs. Een belemmering waarmee de rechter volgens Drion te maken heeft, is dat hij maar een beperkt zicht heeft op de feiten, ondanks de mogelijkheden die rechtsvordering biedt. Drion stelt dat dit deels aan de rechter zelf ligt. Wanneer deze 'opstandiger' met bewijslevering door bijvoorbeeld getuigen zou omgaan, zou volgens hem het zicht op de feiten toenemen. Drion refereert in dit verband aan zijn derde stelling en is van mening dat het bewijs in de civielrechtelijke procesgang onderbelicht blijft. Dit heeft volgens hem te maken met de beperkte tijd die rechters hebben om een zaak af te ronden, en dat zal onder KEI (Kwaliteit en Innovatie) niet beter worden. Het is volgens KEI immers de bedoeling dat in 2018 de doorlooptijden met 40 procent zijn gereduceerd. De door KEI beoogde kortere doorlooptijden kunnen niet bijdragen aan een zorgvuldige feitengaring en daarmee aan procedurele rechtvaardigheid. Een oplossing hiervoor is volgens Drion de mogelijkheid tot het stellen van prejudiciële vragen aan de Hoge Raad, waarvan steeds meer gebruik wordt gemaakt door lagere rechters. Art. 81 lid 1 van de Wet op de rechterlijke organisatie (Wet RO) is minder 'procedureel rechtvaardig'. Dit is volgens Drion echter anders wanneer een zaak gedeeltelijk wordt afgedaan op art. $81 \mathrm{Wet}$ RO, omdat het dan mogelijk is dat de Hoge Raad op enkele andere punten een extensievere motivering geeft. Het is naar de mening van Drion de vraag of men hierover kritisch dient te zijn.

Volgens Drion heeft er een verschuiving plaatsgevonden van partijautonomie naar waarheidsvinding en hij wijst in dit verband op art. 21, 111 en $843 \mathrm{a} \mathrm{Rv}$, de conclusie van antwoord, het bewijsbeslag, de ambtshalve toetsing en de redelijke termijn. De rol van de rechter is veranderd van een 'lijdelijke' in een 'leidende', en daarmee is hij mede verantwoordelijk (geworden) voor de procedurele rechtvaardigheid.

Drion benadrukt dat er in een procedure (veel) meer aandacht zou moeten zijn voor de bewijsvoering. Wat betreft het getuigenverhoor is hij van mening dat advocaten een primaire 
rol zouden moeten spelen bij de bevraging van de getuigen. De rechter zou bij het getuigenverhoor meer de rol van scheidsrechter moeten vervullen. Dit omdat advocaten meer dan de rechter zicht hebben op de feiten. De rechter dient te zorgen voor een professionele vastlegging van het verhoor van een getuige, en volgens Drion zou hierbij ook gebruik kunnen (of moeten) worden gemaakt van geluidsopnamen. Voordeel hiervan is de snelheid. Zorgvuldigheid is echter een groter goed dan de snelheid van de procedure, aldus Drion. De snelheid van de procedure mag volgens hem niet ten koste gaan van de zorgvuldigheid; snelheid zal niet altijd tot 'procedurele rechtvaardigheid' leiden.

Aan het einde van zijn inleiding werpt Drion de vraag op of partijautonomie en waarheidsvinding geen these en antithese zijn, en de 'procedurele rechtvaardigheid' een synthese. Hij eindigt met de stelling dat op alle bij de procedure betrokkenen de verplichting rust om bij te dragen aan rechtvaardigheid, zowel in uitkomst als in procedure.

\section{Discussie}

Op een vraag uit de zaal of het pleidooi voor méér tijd voor de comparitie na antwoord en een uitgebreidere motivering van uitspraken niet op gespannen voet staat met het politieke debat, antwoordt Drion dat dit inderdaad het geval is. Volgens Drion leven we in een tijd dat het eerder de andere kant op gaat, en hij ziet niet in hoe de snelheid van de procedure die met KEI wordt nagestreefd, kan bijdragen aan procedurele rechtvaardigheid. Drion meent dat het daarom van belang is om een tegengeluid te laten horen, ook vanuit de rechtspraak.

Vanuit de zaal wordt ook opgemerkt dat niet vaststaat dat het besteden van aandacht aan procedurele rechtvaardigheid per definitie tot gevolg heeft dat zaken langer duren. Verwezen wordt naar het bestuursrecht en de nieuwe zaaksbehandeling bij de rechtbanken. Het is lastig vast te stellen of de nieuwe zaaksbehandeling leidt tot langere, gemiddeld kortere of gemiddeld ongeveer gelijkblijvende doorlooptijden.

Drion geeft aan dat dit een nuttige aanvulling is op hetgeen al is gezegd. Er zijn volgens hem voorbeelden denkbaar waarbij procedureel rechtvaardig is gehandeld en de doorlooptijden wel degelijk zijn versneld.

Van den Bos geeft aan dat uit een project in Denemarken is gebleken dat het sneller gaat wanneer men een informele behandeling van de zaak toepast. Hij is van mening dat in de rechtspraak de doorlooptijden niet ten koste van de kwaliteit zouden mogen gaan. Het zou volgens hem niet of snellere doorlooptijden of kwaliteit moeten zijn, maar snelle doorlooptijden en kwaliteit.

Van Schaick (advocaat te Tilburg en hoogleraar aan de Universiteit van Tilburg) verwijst naar Drions opmerking over waarheidsvinding en partijautonomie als antithese en these. Hij wijst in dit verband op het arrest Zeug Geel $113 .{ }^{3}$ Volgens Van Schaick is dit arrest wel bevredigend voor zover het de

3. HR 24 februari 1984, NJ 1984/415 (Zeug Geel-113). procedurele rechtvaardigheid betreft. Bij de 'materiële rechtvaardigheid' kunnen daarentegen vraagtekens worden gezet, aangezien de feiten waar de rechter in de diverse instanties van uit is gegaan, niet de feiten waren zoals deze zich in werkelijkheid hadden voorgedaan. Hier ligt volgens hem een belangrijke taak voor de advocatuur, in die zin dat er zodanig wordt geprocedeerd dat bij de rechter een goed beeld ontstaat van wat er (werkelijk) is gebeurd. Van Schaick is dan ook van mening dat partijautonomie - waarvoor een goed functionerende advocatuur een voorwaarde is - en waarheidsvinding geen these en antithese zijn, maar juist twee uitgangspunten die goed samengaan (althans goed samen zouden moeten gaan).

Drion is het eens met Van Schaick. De advocaat moet volgens hem in de partijautonomie niet in zijn partijdige rol worden aangetast, net zomin als de rechter in zijn waarheidsvindingsgedachte moet worden aangetast omdat hij aan procedurele rechtvaardigheid gaat doen.

Röell wil graag ook iets positiefs opmerken over KEI. Het wordt volgens hem nu geassocieerd met bezuinigingen en een ministerie dat zijn werk niet goed doet. Hij ziet echter ook positieve punten van KEI en refereert dan aan de mogelijkheden om met gebruik van audiovisuele middelen een getuigenverklaring op te nemen, waardoor het niet meer nodig is dat de rechter de verklaringen van getuigen moet samenvatten en dicteren. Verder is het volgens Röell mogelijk dat onder KEI een procedure ontstaat die in zekere zin een combinatie vormt van het kort geding en de 'rijdende rechter': afhankelijk van de zwaarte van de zaak kan ieder zijn zegje doen en wanneer de rechter zijn werk goed doet, zal er in beginsel niets onderbelicht (hoeven te) blijven. Er kan dan volgens Röell een snelle afdoening plaatsvinden, vergelijkbaar met het kort geding, en met een grote procedurele rechtvaardigheid.

Drion is het eens met Röell en hoopt dat het zo gaat worden.

Punt (oud-rechter) benadrukt dat een rechter zowel inhoudelijk kwalitatief goed werk moet leveren alsook efficiënt dient te werken. Volgens hem zijn efficiency en kwaliteit niet elkaars tegenpolen. Wel is hier nog het nodige te winnen, maar sinds eind jaren zeventig is er al veel verbeterd in de rechtspraak. In reactie op de inleiding van Van Regteren Altena merkt Punt op dat volgens hem in de praktijk vaak procesverstorend wordt opgetreden door de advocatuur. Hij denkt dat dit een kwaliteitsprobleem is, en het dus van belang is de kwaliteit (van de advocatuur) te verhogen. Volgens Punt is dit een groter probleem dan de balie op dit moment onderkent.

Van Regteren Altena merkt op dat hij heeft willen aangeven dat de discrepantie die er kan zijn tussen de deskundigheid van de advocaat en de partijdigheid, gecorrigeerd zou kunnen worden door de andere kernwaarden, en dan vooral de integriteit. In een concreet geval kan sprake zijn van een dilemma doordat de advocaat de mogelijkheid heeft om door het gebruik van processuele middelen iets te bereiken wat niet direct de bedoeling van de procedure is. In het strafrecht en in 
het bestuursrecht speelt dit dilemma veel pregnanter (en is er ook meer discussie over). Van Regteren Altena refereert aan het door hem gememoreerde debat over de vraag of het openbaar belang wel of niet een aanvullende kernwaarde behoort te worden. In dit verband ging het in het strafrecht onder meer over de vraag of een strafrechtadvocaat die een kinderverkrachter bijstaat, voor vrijspraak mag pleiten wegens een vormfout, wanneer de verdachte aan de advocaat kenbaar heeft gemaakt dat hij het strafbare feit heeft gepleegd. In het bestuursrecht speelde het dilemma of de stichting 'Blije Boom' gebruik mag maken van de mogelijkheden die het bestuursrecht biedt om bezwaar te maken tegen de aanleg/verbreding van een rijksweg, terwijl de aanleg van die rijksweg ertoe leidt dat er veel minder files zullen zijn (hetgeen ook het bnp ten goede komt). In het civiele recht was er minder discussie over dergelijke dilemma's, maar dit betekent niet dat zij in het civiele recht niet zouden bestaan, aldus Van Regteren Altena. Deze dilemma's moeten niet worden verward met het ondeskundig zijn van bepaalde advocaten. Van Regteren Altena benadrukt nogmaals dat een groot aantal procesverstorende gedragingen op de lijst van het onderzoek Een goede procesorde in beeld niet de uitkomst is van een afweging, maar voortkomt uit een kwalitatief tekortschieten van de advocaat. Dit probleem wordt niet opgelost door een prominentere rol aan het openbaar belang toe te kennen. Door selectie, opleiding en bijscholing kan de kwaliteit van de advocaat worden bevorderd, en dat zal uiteindelijk kunnen leiden tot minder procesverstorende gedragingen als gevolg van een gebrek aan deskundigheid.

Gerretsen reageert op de oproep van Drion om debat te krijgen over art. 81 Wet RO. Het gevoel van 'procedurele rechtvaardigheid' wordt volgens Gerretsen enorm gefrustreerd wanneer na een zorgvuldige afweging wordt besloten om in cassatie te gaan en de Hoge Raad in 50 procent van de cassatieberoepen de zaak afdoet op de voet van art. 81 Wet RO. Gerretsen begrijpt het dilemma van de Hoge Raad - motiveringsklachten zijn waarschijnlijk behoorlijk tijdrovend - maar hij vraagt zich af of niet de mogelijkheid kan worden gecreëerd om terug te gaan naar het hof en de motiveringsklachten daar neer te leggen, zodat het hof kan uitleggen waarom het heeft beslist zoals het beslist heeft. Dit zou volgens Gerretsen in de vorm van een verlofstelsel kunnen worden gegoten.

Röell laat een ander geluid horen. Hij is van mening dat het uitstekend is dat de Hoge Raad een selectie maakt. Er is immers niet alleen de verkorte afdoening, maar ook de conclusie van de A-G waarin waardevolle informatie staat. Gerefereerd wordt aan het Supreme Court in de Verenigde Staten, waar helemaal niet wordt gemotiveerd waarom een zaak wel of niet in behandeling wordt genomen. De weg naar de Hoge Raad zou alleen open moeten staan in die gevallen waarin onmiskenbaar een fout is gemaakt door de rechtbank of het hof, aldus Röell.

Hulst (onderzoeker aan de Vrije Universiteit te Amsterdam) wil graag een aanvulling doen op de inleiding van Van den
Bos. Ervaren procedurele rechtvaardigheid zijn de subjectieve indrukken die mensen zich vormen van hoe ze behandeld worden, en dat is anders dan een normatief iets van hoe het moet; en het is ook niet zo dat een procedure er zo uit moet zien of een motivering zo moet zijn, en dat die indruk dan altijd hetzelfde zou zijn. Procedurele rechtvaardigheid is volgens Hulst dus niet iets normatiefs en dit is belangrijk om voor ogen te houden bij het verder nadenken over procedurele rechtvaardigheid en wat daaraan bijdraagt.

Drion merkt op dat art. 81 Wet RO een noodzakelijk kwaad is. Het is volgens hem 'kwaad' en het is 'noodzakelijk' op dit moment. Er zijn zaken die art. $81 \mathrm{Wet} \mathrm{RO}$ verdienen omdat de daarin naar voren gebrachte middelen niet uitblinken in kwaliteit. Drion geeft aan dat dit een van de gronden is waarop de Hoge Raad dan de zaak afdoet op art. 81 Wet RO. Natuurlijk zijn er ook zaken waarin prachtige motiveringsklachten zijn aangevoerd, en dan is het vervelend voor de advocaat en nog vervelender voor de cliënt als de zaak op art. 81 Wet RO wordt afgedaan. Maar Drion benadrukt dat ook wanneer een zaak via art. $81 \mathrm{Wet} \mathrm{RO}$ wordt afgedaan, er zorgvuldig naar is gekeken en hij wil graag - als bij de balie de indruk zou bestaan dat dit niet het geval is - deze indruk hierbij wegnemen.

Giesen (hoogleraar aan de Universiteit Utrecht) heeft een aanvulling op de discussie over art. 81 Wet RO. Volgens hem moet de cliënt de procedurele rechtvaardigheid al ervaren hebben bij de procedure in eerste aanleg en desnoods in het hoger beroep. Giesen is voorstander van handhaving van art. $81 \mathrm{Wet}$ RO.

In reactie hierop merkt Gerretsen op dat Giesen situaties over het hoofd ziet waarin de uitspraak in eerste aanleg en die in hoger beroep diametraal tegenover elkaar staan. De 'repliek' van Giesen: maar dan zijn partijen al wel twee keer (door de rechter) gehoord.

De Groot (raadsheer bij de Hoge Raad) refereert aan de opmerking van Van den Bos dat het heel moeilijk is om een systematisch wantrouwen - tegen anderen en tegen maatschappelijke instituties - langdurig vol te houden; zij vraagt zich af wat we daarmee kunnen als we procesverstorend gedrag zien, en wat we kunnen doen om die ander ertoe te bewegen dat niet (meer) te doen.

Volgens Van den Bos zijn er wel strategieën uit de onderhandelings- en conflictoplossingsliteratuur die goed werken, zoals 'tit for tat'. Dit houdt in dat je je coöperatief opstelt en als de ander zich dan competitief (of anderszins onheus) opstelt, je dat een keer terugdoet en je vervolgens weer coöperatief opstelt. Het coöperatief opstellen wordt volgens Van den Bos nog wel eens vergeten. Op het moment dat mensen inderdaad met een geschil bij bijvoorbeeld de rechter komen, kan worden geprobeerd met een dergelijke strategie het conflictueuze uit zo'n relatie of interactie te halen.

Van Regteren Altena wil hier nog aan toevoegen dat de rechter de zaken waarin partijen over en weer voldoende 
coöperatief zijn of met het nodige 'duw- en trekwerk' tot 'coöperativiteit' zijn te bewegen (en die eindigen door een schikking) niet of nauwelijks onder ogen krijgt. De zaken die uiteindelijk voor de rechter komen (na afweging en het presenteren van alternatieven), zijn meer dan eens de zaken waarin de advocaten te maken hebben met lastige cliënten, waarbij de advocaat vaak al herhaaldelijk vruchteloos heeft geprobeerd om partijen tot inschikkelijkheid te bewegen. In zulke zaken kan men volgens Van Regteren Altena toch nog ter zitting tot een schikking komen wanneer de advocaat zijn cliënt goed voorbereidt op de zitting en ook aangeeft waar de pijnpunten in de zaak zitten.

De laatste vraag wordt gesteld aan Van den Bos. Er is een (heel) klein percentage mensen die basaal wantrouwend zijn; is er dan - voor een rechter - nog enige hoop om die mensen een gevoel van procedurele rechtvaardigheid te geven?

Van den Bos antwoordt dat hij denkt dat hieraan in de maatschappij of via scholing heel veel kan worden gedaan. Er kan dus niet iets ter zitting worden gedaan, maar wel in het stadium daarvoor door gebruik te maken van controlerende mechanismen.

De voorzitter geeft ter afronding een korte conclusie, dankt de sprekers en sluit de vergadering. 